\title{
Effects of $₫-3$ Fatty Acids on Liver Function Tests in Patients with Diabetes Mellitus
}

\author{
Tamanna Binte Habib *1, Qazi Shamima Akhter ${ }^{2}$, Hasan Imam ${ }^{3}$, Nahid Yeasmin ${ }^{4}$
}

\begin{abstract}
Introduction: Patients with type-2 Diabetes are augmented the risk of non alchoholic fatty liver disease that rises liver enzymes and total protein. To observe the favourable effects of fish oil capsule on liver function tests in patients with type 2 DM. Materials and Methods: A prospective interventional study was conducted from January 2017 to December 2017. A total numbers of 52 diagnosed type 2 diabetic patients of both sexes were scrutinized with age ranging from 40 to 50 years. Among them, 27 type 2 diabetic patients those who taken oral fish oil gel (2g/day) for 12 weeks were preferred as study group. Another 25 type 2 diabetic patients without supplementation of omega 3 fatty acid were nominated as control group for comparison. The study subjects were selected from Dhaka Medical College Hospital, Dhaka and personal contact from Dhaka city on the basis of criteria. The research work was administrated with ethical clearance from concerned authority. Results: In this study ALP, LDH, total protein were reduced in diabetic patients after supplementation with omega-3 fatty acid in comparison to that of their baseline value. Again, after 12 weeks, ALP (Alkaline Phosphatase) LDH (Lctate dehydrogenase) and total protein were decreased in diabetic patients after supplementation with omega-3 fatty acid in comparison to control group. Conclusion: After analyzing the results of the study, it can be concluded that omega-3 fatty acid can reduce ALP, LDH and total protein levels in diabetic patients may be helpful to minimize the risk of fatty liver in type-2 diabetes mellitus.
\end{abstract}

Key words: Diabetes mellitus, Fatty liver, ALP, LDH, Total protein and Omega-3 fatty acid.

Number of Tables: 02; Number of References: 23; Number of Correspondence: 04.

*1. Corresponding Author:

\section{Dr. Tamanna Binte Habib}

Lecturer, Department of Physiology

Dhaka Medical College, Dhaka.

E-mail: tamannapompy1234@gmail.com

or hshimul09@gmail.com

Mobile Number: 01750883457, 01716320421

2. Dr. Qazi Shamima Akhter

Professor \& Head, Department of Physiology

Dhaka Medical College, Dhaka.

E-mail: shamimaqazi@yahoo.com.

3. Dr. Hasan Imam

Graded Specialist, Department of Anesthesia

Combined Military Hospital, Bogra.

E-mail:hshimul09@gmail.com.

\section{Dr. Nahid Yeasmin}

Assistant Professor, Department of Physiology

Dhaka Medical College, Dhaka.

Email: nahidyeasmin@gmail.com.

\section{Introduction}

Diabetes mellitus (DM) is one of the multifactorial disorder characterized by hyperglycemia related with carbohydrate, protein and fat metabolism. The chronic hyperglycemia of diabetes is associated with long term damage of liver can causes non alchoholic fatty liver disease ${ }^{1}$. Diagnostic criteria of diabetes mellitus are fasting plasma glucose level $\geq$ $7.0 \mathrm{mmol} / 1(126 \mathrm{mg} / \mathrm{dl})$ or plasma glucose 2 hours after an oral glucose $\geq 11.1 \mathrm{mmol} / \mathrm{L}(200 \mathrm{mg} / \mathrm{dl})$ and $\mathrm{HbA} 1 \mathrm{c} \geq$ $6.5 \%{ }^{2}$.Within 2030 , the extensiveness of diabetes mellitus will be 11.1 million in Bangladesh ${ }^{3}$.The prevalence of NASH is steadily increasing and prevalent in patients of Diabetes mellitus ${ }^{4}$.

The pancreatic hormone named insulin is needed for tissue development, growth and maintenance of whole body glucose homeostasis. Insulin maintains glucose homeostasis by improving the rate of glucose uptake into skeletal muscle and fat tissue. In the skeletal muscle, insulin fascilitates glucose uptake by stimulating translocation of GLUT-4 to plasma membrane ${ }^{5}$. Insulin resistance occurs when the insulin sensitive tissue loses response to insulin. The basic effect of insulin resistance on glucose metabolism is to oppose the uptake and utilization of glucose by most cells of the body. As a result blood glucose concentration rises, cell utilization of glucose falls, utilization of fat increases and free fatty acid level increases in blood $^{6}$.

๑-3 Fatty acids are polyunsaturated fatty acids consists of alphalinolenic acid (ALA), eicosapentaenoic acid (EPA) and docosahexanoic acid (DHA). They are found mainly in seafish including fatty fish (e.g. salmon, tuna and trout) and shellfish (e.g. crab, mussels and oysters). The omega 3 fatty acid; stimulates insulin sensitivity, reduces blood clotting, improves fat digestion, boost up fertility, lessen depression and causes brain development in babys ${ }^{7}$.

Consumption of fish oil can decreases free fatty acid level, promotes insulin sensitivity as well as reduce the incidence of type $2 \mathrm{DM}^{8}$. Omega-3 capsule act directly on insulin sensitive tissues, rises number of insulin receptors thus inhibits insulin resistance ${ }^{9}$. Intake of food rich in omega-3 fatty acid, facilitate the action of insulin through various metabolic pathways, which are reduction of hepatic lipogenesis, suppression of the release of triglycerols from liver, improvement in ketogenesis, and oxidation of fatty acids in hepatic
91 Received: 25 March 2020
Accepted revised version: 07 July 2020 
cells ${ }^{10}$. Non alchoholic fatty liver diseases are very common in type 2 diabetic patients ${ }^{11}$. Moreover, intake of polyunsaturated fatty acid decreases serum ALP and GGT level ${ }^{12}$.

Omega- 3 fatty acid prevents this change by increasing peroxisome proliferator receptor gamma, increasing hepatic uptake and oxidation of free fatty acid in striated muscle ${ }^{13}$.Therefore the present study is intended to assess the effect of supplementation of omega- 3 fatty acid in Bangladeshi diabetic patient that reduce liver enzymes.

\section{Materials and Methods}

This prospective, interventional study was administrated from Department of Physiology, Dhaka Medical College, Dhaka from January 2017 to December 2017. The research work was carried-out by obtaining ethical clearance from related departments, Research Review Committee and Ethical Review Committee of Dhaka medical college, Dhaka. The patients were selected from outdoor of Endocrinology, Dhaka medical college and personal contact from Dhaka city. At the beginning of study 60 diagnosed type- 2 diabetic patients were randomly nominated on the basis of exclusion and inclusion criteria. There were 30 patients of control group and 30 patients of study groups scrutinized for study purpose, After 6 weeks of study period, 3 patients were relinquished from study group and 5 patients were dropped out from control group. Finally, total 52 type diabetic patient of both sexes with the age ranging from 40-50 years with FBG $7.0 \mathrm{mmol} / 1$ or $126 \mathrm{mg} / \mathrm{dl}$, HbA1c $6.5 \%$, serum total cholesterol $>200$ $\mathrm{mg} / \mathrm{dl}$, serum triglyceride $>150 \mathrm{mg} / \mathrm{dl}$, LDL $>130 \mathrm{mg} / \mathrm{dl}$, $\mathrm{BMI} \leq 30 \mathrm{Kg} / \mathrm{m}^{2}$ and patients with oral hypoglycemic drug were included in this study. Fatty liver was diagnosed by abdominal ultra-sonography subjects having history of heart, endocrine disorder, insulin therapy, viral hepatitis, acute or chronic infections, pregnant and lactating women were excluded from this study. For this study 27 diagnosed type-2 diabetic patients with omega- 3 fatty acid supplementation were selected as study group and 25 type-2 diabetic patients without oral omega-3 fatty supplementation were selected as control group. The study group again segmented into pre-supplementation group and after 12 weeks of supplementation as post supplementation group. The control group was sub-divided as pre and post follow-up group. After selection, the nature, purpose and benefits of the study were explained to each subject and informed written consent was taken from participants. Before taking blood detailed family and medical history were taken. Anthropometric measurement of the subjects was recorded and blood pressure was measured. All the information were recorded in a prefixed questionnaire. With aseptic precaution, $5 \mathrm{ml}$ of venous blood was obtained from ante-cubital vein by a disposable plastic syringe from each subject after overnight fasting for biochemical tests. Serum ALP and GGT was estimated by enzymatic colorimetric method in auto-analyzer in department of Laboratory Medicine Dhaka Medical College Hospital, Dhaka. Omega-3 fatty acid (2gm) was supplied to study group then they were asked to intake twice daily for 12 weeks with proper directions. Patients were instructed not to change their diet and physical activities during the course of the study. A regular telephonic communication and periodic visit was made to participants because most of them are staff of Dhaka medical college. For statistical analysis, Paired Student's ' $t$ ' test and Unpaired Student's ' $t$ ' test were performed as applicable using SPSS for windows version 16.0. Data were expressed as mean \pm SE. The $p$ value of $<0.05$ was accepted as level of significance.

\section{Results}

In this study no significant difference were seen in age, sex, BMI, systolic and diastolic blood pressure between study and control group (Table I).

Table -I: General characteristics of the patients in both groups $(\mathrm{N}=52)$.

\begin{tabular}{l|c|c}
\hline Parameters & $\begin{array}{c}\text { Study group } \\
(\mathrm{n}=27)\end{array}$ & $\begin{array}{c}\text { Control group } \\
(\mathrm{n}=25)\end{array}$ \\
\hline Age (years) ${ }^{\mathrm{a}}$ & $45.90 \pm 3.80$ & $44.92 \pm 3.75$ \\
$\begin{array}{l}\text { Sex }(\%)^{\mathrm{b}} \\
\text { Male }\end{array}$ & $18(66.7 \%)$ & $11(44 \%)$ \\
$\quad$ Female & $9(33.3 \%)$ & $14(56 \%)$ \\
BMI (kg/m $)^{2}$ & $25.03 \pm 2.27$ & $25.87 \pm 1.75$ \\
$\begin{array}{l}\text { Systolic BP } \\
(\mathrm{mmHg})\end{array}$ & $119.07 \pm 7.08$ & $121.79 \pm 4.47$ \\
$\begin{array}{l}\text { Diastolic BP } \\
(\mathrm{mmHg})\end{array}$ & $79.63 \pm 6.26$ & $80.00 \pm 0.00$ \\
$\begin{array}{l}\text { Duration of } \\
\text { disease }\end{array}$ & $5.43 \pm 1.50$ & $5.35 \pm 1.57$ \\
\hline
\end{tabular}

Results were expressed as mean \pm SD. a=Unpaired Student's ' $t$ ' test was performed to compare between the groups. $b=$ Chi Square test was performed to compare male and female between the groups. The test of significance was calculated and $\mathrm{p}$ value $<0.05$ was accepted as level of significance. $\mathrm{N}=$ total number of subjects, $\mathrm{n}=$ number of subjects in each group $\mathrm{ns}=$ non-significant $* / * * / * * *=$ significant. T2DMS=Type 2 diabetes mellitus with supplementation T2DM=Type 2 diabetes mellitus without supplementation.

In this study, the mean serum ALP and GGT levels were almost similar and there is no statistical difference were observed at the beginning of the study. In study group, the mean serum ALP $(p<.0 .01)$ and mean serum GGT $(p<.01)$ level were found remarkable lowe in post supplementation group, than pre-supplementation group. Again the mean serum ALP $(\mathrm{p}<.01)$ levels and mean serum GGT $(\mathrm{p}<.01)$ levels were found significantly lower and in study group compared to control group. In control group, there was no statistical dissimilarity were perceived in mean serum ALP and GGT between pre-follow-up and post follow-up group. 
Table-II: Serum Alkaline phosphatase, serum lactate dehydrogenage and total protein levels in different groups $(\mathrm{N}=52)$.

\begin{tabular}{|l|l|l|l|l|}
\hline \multicolumn{1}{|c|}{ Parameters } & \multicolumn{2}{|c|}{$\begin{array}{c}\text { Study group } \\
(\mathrm{n}=27)\end{array}$} & \multicolumn{2}{c|}{$\begin{array}{c}\text { Control group } \\
(\mathrm{n}=25)\end{array}$} \\
\hline & $\begin{array}{l}\text { Pre- } \\
\text { supplemenation } \\
\text { group }\end{array}$ & $\begin{array}{l}\text { Post supplementation } \\
\text { group }\end{array}$ & $\begin{array}{l}\text { Pre-follow-up } \\
\text { group }\end{array}$ & $\begin{array}{l}\text { Post follow - } \\
\text { up group }\end{array}$ \\
\cline { 2 - 5 } & $74.6 \pm 2.71$ & $38.5 \pm 1.67^{* *}$ & $69.20 \pm 4.20$ & $61.96 \pm 4.43^{\# \#}$ \\
ALP(IU/L) & $150.3 \pm 4.03$ & $142.5 \pm 1.02^{*}$ & $147.00 \pm 2.64$ & $146.6 \pm 2.21^{\# \#}$ \\
LDH(U/L) \\
$\begin{array}{l}\text { Total } \\
\text { protein(g/dl) }\end{array}$ & $11.06 \pm 2.01$ & $8.1 \pm 1.1^{*}$ & $10.06 \pm 1.02$ & $9.8 \pm 1.4^{\#}$ \\
\hline
\end{tabular}

Results are expressed as mean \pm SD. $a=$ Paired student's $t$ test was performed for comparison within groups and $\mathrm{b}=$ unpaired $\mathrm{t}$ test was performed to compare between groups. $\mathrm{p}$ value $<0.05$ was accepted as level of significance. $\mathrm{N}=$ total number of subjects, $\mathrm{n}=$ number of subjects in each group, ALP=Alkaline Phosphatase, GGT $=$ Gamma glutamyl transeferase $(*=$ study group baseline vs study group after 12 weeks of supplementation; \# = study group after 12 weeks vs control group after 12 weeks); $(* \mathrm{p}<.01, * * \mathrm{p}<0.001$; \# $\mathrm{p}<.01$, \# $\mathrm{p}<0.001$ ).

\section{Discussion}

In the present study, the mean serum ALP and GGT levels were reduced in patients of T2DM after supplementation with omega-3 fatty acid in comparison to that of their baseline value. Again, after 12 weeks, mean high density lipoprotein (.01) level was significantly higher in type-2 diabetic patients supplemented with omega-3 fatty acid in comparison to that of diabetic control group without omega-3 fatty acid capsule. Insulin resistance leads impaired fatty acid oxidation in liver that causes accumulation of fat in liver ${ }^{14}$. When diabetic patient suffers from non alchoholic fatty liver diseases ALP and GGT rises ${ }^{15}$. Almost similar type of result were seen by different researchers of different countries ${ }^{16,17}$. On the contrary, found no significant difference in lipid profile in patients after supplementation of omega- 3 fatty acid in comparison to that of their baseline values and diabetic control group who were not supplemented with omega-3 fatty acid. There were a history of less physical activity in the study subjects that might be contributed the result of those study. Literature review suggested that, when fat stored in liver it leads to rise serum triglyceride level. When serum triglyceride level rises it rises serum ALP and GGT levels ${ }^{18}$. The binding of insulin with its receptor through releasing some inflammatory mediator from liver, that decreases insulin receptor signaling activity, this facts are influenced by rising serum TG level.Omega-3 fatty acid has a role on reducing serum triglyceride level. Peroxisome proliferator receptor $-\alpha$ exists in the liver which increase in number in presence of omega- 3 fatty acid. An increase in PPAR- $\alpha$ leads to hepatic uptake of free fatty acid. It also uprise the free fatty acids oxidation in skeletal muscle. As a result, free fatty acid level is reduced in blood. The consequence of free fatty acid reduction helps to decrease triglyceride synthesis. Thus, fish oil capsules reduces serum triglyceride level that promotes the binding of insulin to its receptor and enhances insulin sensitivity ${ }^{19}$. Fish oil activate PPAR-@ (peroxisome proliferator activated receptor alpha) and down regulate sterol regulatory element binding protein-1c (SREBP-1)that enhance fatty acid oxidation and decreases liver enzymes ${ }^{11}$. Modulation of Alkaline Phosphatase enzyme can be done by dietary fish oil ${ }^{20}$. Fish oil supplements lowers plasma lactate dehydrogenage that's releases from endoplasmic reticulum and improve glucose tolerance by molecular mechanism ${ }^{21}$. In diabetic patient total protein level rises ${ }^{22}$. Supplementation of fish oil capsule decreases protein synthesis signaling so total protein decreases ${ }^{23}$.

In the present study serum ALP, LDH and Total protein levels decreases in patients with T2DM after supplementation of omega-3 fatty acid in contrast to their baseline value and control group. Omega-3 fatty acid supplementation lessen ALP and LDH by increasing fatty acid oxidation and alter signaling pathway of protein and decreases total protein.This premises the binding of insulin to its receptor and improves insulin sensitivity.

\section{Conclusion}

After analyzing the results of the study, it can be concluded that supplementation of omega-3 fatty acid can reduces serum ALP and GGT levels in patients with type-2 diabetes mellitus. Therefore, omega-3 fatty acid containing diet may be useful to keep down the complications in type-2 diabetes mellitus.

\section{Conflict of Interest: None.}

\section{Acknowledgement}

The authors are thankful to the study subjects for their active, sincere and voluntary participation.

\section{References}

1. Jun DW, Kim HZ, Bae JH, Lee OY.The clinical significance of $\mathrm{HbA} 1 \mathrm{c}$ as a predictive factor for abnormal postprandial glucose metabolism in NAFLD patients with an elevated liver chemistry. Hepatogastroenterology. 2011; 58: 1274-79.

https://doi.org/10.5754/hge10729

PMid:21937392

2. World Health Organization. Definition and diagnosis of diabetes mellitus and intermediate hyperglycemia: Report of a WHO/IDF. Consultation. [Internet].Geneva: World Health Organization;2011. [Cited 2017 May 18].Available from; https://www.idf.org.

3. Baynest HW. Classification, pathophysiology, diagnosis and management of diabetes mellitus. $\mathbf{J}$ of Diabetes Metab. 2015; 6:1-13.

https://doi.org/10.4172/2155-6156.1000541 
4. Vernon G, Baranova A, Younossi ZM. Systemic review : the epidemiology and natural history of non-alchoholic fatty liver disease and nonalchoholic steatohepatititis in adults. Aliment Pharmacol Ther. 2011; 34: 274-85.

https://doi.org/10.1111/j.1365-2036.2011.04724.x

\section{PMid:21623852}

5. Pessin JF and Saltiel S. Signaling pathways in insulin action: molecular targets of insulin. The $\mathrm{J}$ of Clin inv. 2000; 106(2) : 155-69.

https://doi.org/10.1172/JCI10582

PMid:10903329 PMCid:PMC314316

6. Delarue J and Magnan C. Free acids and insulin resistance. Research Gate. 2014; 10(1): 142-48.

https://doi.org/10.1097/MCO.0b013e328042ba90

PMid: 17285001

7. National Center for Complementary and Integrative Health n.d., Omega-3 supplements in depth. [Interenet] 2017[Cited on April 23]2017. Available from:

http://nccih.nih.gov//omega-3 supplements in depth/html 8. Albert BB, Derraik JGB, Brenan CM, Smith GC, Glarg ML, Smith DC, et al. Higher omega-3 index is associated with increased insulin sensitivity and more favourable metabolic profile in middle-aged overweight men. Sci Rep. 2014; 4: 1-8.

https://doi.org/10.1038/srep06697

PMid:25331725 PMCid:PMC5381193

9. Laila AZ and Lanza IR. Insulin -Sensitizing effects of omega-3 fatty acids: lost in translation. Nutr. 2016; 8 (6): $1-24$.

https://doi.org/10.3390/nu8060329

PMid:27258299 PMCid:PMC4924170

10. Portillo-Sanchez P. High prevalence of Nonalchoholic Fatty Liver Disease in patients with type 2 Diabetes Mellitus and normal plasma Amnotranseferase level. J Clin Endocrinol Metab. 2015; 100(6): 2231-38.

https://doi.org/10.1210/jc.2015-1966

\section{PMid:25885947 PMCid:PMC6287506}

11. Parker HM, Johnson NA,Burdon CA,Cohn JS.Omega-3 PUFA supplementation and non alchoholic fatty liver disease. J Hepatol. 2012; 56: 944-51.

https://doi.org/10.1016/j.jhep.2011.08.018

PMid:22023985

12. Lopez AL, Ramos RV, Carrillo BE. Type 2 Diabetes, PUFAs and vitamin D: their relation to inflammation. $\mathbf{J}$ of Immun Res. 2014; 1: 1-14.

https://doi.org/10.1155/2014/860703

PMid:24741627 PMCid:PMC3987931
13. Harikrashna B.Bhat,Robert J.Smith.Fatty liver diseases in Diabetes mellitus.Hepatobilliary Surg Nutr. 2015;4(2):101-08.

14. Mandal A, Bhattarai B, Kafle P, Khalid M. Elevated liver enzymes in patients with Type-2 Diabetes Mellitus and $\mathrm{N}$ on alchoholic fatty liver disease. Curious. 2018; 10: 1-9. https://doi.org/10.7759/cureus.3626

15. Shresta N, Bhatt NP, Neopane P, Dahal S. Hepatic involvement with elevated liver enzymes in Nepalese subjects with Type- 2 diabetes mellitus. Int $\mathbf{J}$ of Biochem Res Rev. 2017; 16: 1-8.

https://doi.org/10.9734/IJBCRR/2017/31935

16. Ni H, Soe HHK, Htet A. Determinants of abnormal liver function tests in diabetes patients in Myanmar. Int J Diabetes Res. 2012; 1: 36-41.

https://doi.org/10.5923/j.diabetes.20120103.02

17. Jameil NA, Khan FA, Arjumand S, Khan MF, Tabassum H. Associated liver enzymes with hyperlipidemic profile in type 2 diabetes patients. Int $\mathbf{J}$ Clin Exp Pathol. 2014; 7(7): 4345-49.

18. Shidfar F, Keshavaraz A, Hosseyni S, Ameri A. Effect of omega -3 fatty acid supplements on serum lipids, apo-lipopotein and malondehyde in type 2 diabetes patient. East Mediterranean Health J. 2008; 14(2): 305-12. 19. Fernandez ML and West KL. Mechanism by which Dietary Fatty Acids Modulate Plasma Lipids. J Nutr. 2005; 135: 2075-78.

https://doi.org/10.1093/jn/135.9.2075

PMid: 16140878

20. W Rachel, C Uri and M Shoshana. Dietary fish oil modulates the Alkaline Phosphatase Activity and not the fluidity of Rat Intestinal Microvillous Membrane. The $\mathrm{J}$ of Nutr. 1992; 122(5): 1077-84.

https://doi.org/10.1093/jn/122.5.1077

PMid: 1564560

21. T.Chiam, ML Tsai. Effect of fish oil on plasma lipoprotein,liver glucose-6-phosphat dehydrogenage and glucose-6 phosphatase in rats. Int J Vitam Nutr Res. 1995; 65(4):276-282.

22. Gul A, Rahman MA.Comparison of blood protein levels between diabetic and non diabetic patients with retinopathy. J Coli Physicians Surg Pak. 2016;16(6): 408-411

23. Marzuca GN. Effects of high EPA and High DHA fish oil on changes in signaling associated with protein metabolism. The Physiol Society. 2016; 4 (18) http://doi.org/10.14814/phy2.12958 